\title{
LEXICAL FEATURES OF INTERLINGUAL HOMONYMS IN MODERN PERSIAN, DARI AND TAJIK
}

\author{
RECURSOS LÉXICOS DE HOMÔNIMOS INTERLINGUÍSTICOS EM PERSA, DARI E \\ TADJIQUE MODERNOS
}

\author{
CARACTERÍSTICAS LÉXICAS DE LOS HOMÓNIMOS INTERLINGÜES EN PERSA \\ MODERNO, DARI Y TAJIK
}

\author{
Mastura N. AKHMEDOVA ${ }^{1}$ \\ Ramil T. YUZMUKHAMETOV ${ }^{2}$ \\ Iles M. ABROROV ${ }^{3}$ \\ Inessa G. BELOGLAZOVA ${ }^{4}$ \\ Azim BAYZOEV 5
}

\begin{abstract}
The relevance of the researched problem is caused by the need to study the lexical features of these languages, and to show students a real linguistic situation when studying the Persian language. The aim of the article is to consider the lexical features of interlingual homonyms in modern Persian, Dari and Tadjique. The leading approach in the studying of this issue is a problem-thematic approach. The study of interlingual homonyms in terms of their features and the review of the situations in which they are used in the Persian and Tadjique languages, shows the possible approaches to the description of their semantics [19, 281]. And at its queue this is a new direction in the modern Persian lexicography, which is of a great scientific benefit. The submissions of this article may be useful in the teaching of the modern Persian, Tadjique, Dari languages as well as when lecturing on the lexicology and dialectology of Persian, Tadjique, Dari.
\end{abstract}

KEYWORDS: Persian language. Dari and tadjique. Lexical differences. Interlingual homonyms.

RESUMO: A relevância do problema pesquisado deve-se à necessidade de estudar as características lexicais dessas línguas, e de mostrar aos alunos uma situação linguística real no estudo da língua persa. O objetivo do artigo é considerar as características lexicais dos homônimos interlinguísticos no persa, dari e tadjique modernos. A abordagem principal no

\footnotetext{
${ }^{1}$ Kazan Federal University (KPFU), Kazan - Russia. Associate Professor of the Department of Oriental and African Studies, and Islamic Studies. ORCID: https://orcid.org/0000-0001-7899-1682. E-mail: ahmadova_74@mail.ru

${ }^{2}$ Kazan Federal University (KPFU), Kazan - Russia. Associate Professor of the Department of Oriental and African Studies, and Islamic Studies. ORCID: https://orcid.org/0000-0001-8104-0773. E-mail: ramil.yuzmukhametov@mail.ru

${ }^{3}$ Kazan Federal University (KPFU), Kazan - Russia. Senior Lecturer of the Department of Oriental and African Studies, and Islamic Studies. ORCID: https://orcid.org/0000-0002-0252-3011. E-mail: ilyas-muhrim@mail.ru ${ }^{4}$ Kazan Federal University (KPFU), Kazan - Russia. ssistant of the Department of Oriental and African Studies, and Islamic Studies. ORCID: https://orcid.org/0000-0002-5105-299X. E-mail: igbeloglazova@gmail.com

${ }^{5}$ Tajik National University (TNU), Dushanbe - Tajikistan. Associate-Professor of the Department of Oriental Studies. ORCID: https://orcid.org/0000-0003-3655-354X. E-mail: azim_b@mail.ru
} 
estudo desta questão é uma abordagem problema-temática. O estudo dos homônimos interlinguísticos em termos de suas características e a revisão das situações em que são usados nas linguas persa e tadjique, mostra as abordagens possiveis para a descrição de sua semântica [19, 281]. E em sua fila esta é uma nova direção na lexicografia persa moderna, que é de grande beneficio científico. A submissão deste artigo podem ser úteis no ensino das linguas persa, tadjique e dari modernas, bem como nas palestras sobre lexicologia e dialetologia persa, tadjique e dari.

PALAVRAS-CHAVE: Língua persa. Dari e Tadjique. Diferenças lexicais. Homônimos interlinguísticos.

RESUMEN: La relevancia del problema investigado se debe a la necesidad de estudiar las características léxicas de estos idiomas, y mostrar a los estudiantes una situación lingüística real al estudiar el idioma persa. El objetivo del artículo es considerar las características léxicas de los homónimos interlingüísticos en persa, dari y tayiko modernos. El enfoque principal en el estudio de este tema es un enfoque temático de problemas. El estudio de los homónimos interlingüísticos en términos de sus características y la revisión de las situaciones en las que se utilizan en las lenguas persa y tayika, muestra los posibles enfoques para la descripción de su semántica [19, 281]. Y en su cola esta es una nueva dirección en la lexicografía persa moderna, que es de gran beneficio cientifico. Las presentaciones de este artículo pueden ser útiles en la enseñanza de los idiomas persa, tayiko y dari modernos, así como para dar conferencias sobre lexicología y dialectología del persa, tayiko y dari.

PALABRAS CLAVE: Lenguaje persa. Dari y Tadjique. Diferencias léxicas. Homónimos interlingüisticos.

\section{Introduction}

Despite of the fact that the modern Persian, Tajik and Dari languages are the branches of the New Persian language (or the so-called classical Persian-Dari), nowadays there are fundamental changes in both colloquial and literary speech in these languages (OTHEGUY; GARCÍA; REID, 2015, p. 442). In fact, the modern Persian language of Iran, Tajik and Dari languages under the influence of the Arabic and European languages are very different from each other in their dialects. It should be said that the difference is present naturally both in the phonetic and lexical structure of the languages. Many similar words used in the Iranian Persian, Tajik and Dari of Afghanistan, in the semantic meaning are different, most of these words were used in the classical period of the language and seen in the works of the classical masters of poetry.

Russian linguist Oranskiy (1352, p. 257) which considered dialects and sub-dialects of the modern Iranian languages, when watching a lot of differences between the dialects of these lingual regions said: 'in the Central Areas of Iran and Persia a lot of local dialects and sub- 
dialects were spread. These dialects are so different and various, from the point of view of their current situation, sometimes you can consider them as a different separate linguistic unit each.

One of the important features in the difference between the words in these languages is matching of dialectal units of the modern Persian dialects to the words and dialects of Tajik and Dari. Lazar (2008, p. 103), a French Iranist, who has researched mostly the language of the texts of the classical period, as well as the historical dialectology, confirms that a number of words of the tenth century, which was formed during the development of the literary language, were still preserved and used in the dialects of Persian and Tajik.

However, these words are different by their semantic meanings in a particular language. It should be noted that the semantic fields of the words are not clear. Some of them are made in respect to homonymous, and some have polysemantic meanings. Since in both cases, there is a semantic change of the meanings of the words, we explain them altogether.

\section{Methodological framework}

In related languages sometimes a phenomenon occurs in which one type of the word occurs in two or more languages with the difference semantics. Generalizing the specific features of the semantic word-measuring and the factors that regulate these features, we include such units similar to the interlingual homonyms. In our opinion, it is difficult to understand the nature and lexical features of this class of homonyms in these languages, since any medium of a language represents them to itself by the nature of their personality. Misunderstanding of interlingual homonyms in these languages distorts their inner motives and are not associated with the meaning of a homonymous resultative.

The words below were changed by the semantic meaning and is currently used in various meanings: The unit 'kat' in the Persian language has the following homonymous meanings: [kat] I colloquial shoulder; [kat] II 1) a broad wooden bench or a bed; 2) arch. throne; [kat] III dial. irrigation canal, ditch, karez; [kat] IV contraction of [keat, ke torā] - 'you, to you' (RUBINCHIK, 1983, p. 308).

Muhammmad Muin in his dictionary mentioned only two meanings of this word (MOIN, 2008, p. 855). In the explanatory dictionary of the Tajik language this word is explained in two ways: kat 1. throne, the Shah's throne; 2. couch for sitting and sleeping (SHUKUROV; KAPRANOV, 1969, p. 543). 
Gardezi in 'Zayn al-Akhbor' states: 'kat' was in the meaning of the 'throne' and this word is still preserved in Afghanistan, Persia, and in the Pashto language' (DAVLATOVA, 1969; SHUKUROV; KAPRANOV, 1969).

But this very word with the meaning of 'to look from hiding'; 'to lie in ambush' [gorbe kat kard] in the language of Bakhtiari in Iran and 'a special wooden seat, couch' in the Tajik dialects is in the homonymous respect. The word [kat] in the southern dialects of the Tajik language has the following meanings: 1. 'outdoor canopy', 'gazebo'; 2. 'props for vines', 'trellises' (in Fathabad in Kalai Labi Obi Garm) as well as the meaning of 'stretchers for the dead' (in the Sangtuda Dangara) (NEMENOVA; JURAEV,1980, p. 244).

In the dialects of Persian and Tajik there is also a unit [katak], which was formed by the same word using the diminutive suffix '-ak', which has a different semantics. In the modern Persian, Dari and Tajik languages, the word 'Katak' is known to mean 'a chicken coop', 'a place for keeping birds', 'cage' [katake morgh/katake parande], and in the dialects of those languages is used in the various semantic shades. In the southern dialect of the Tajik language in Karategin it is used to refer to a wooden object, 'the niche or place near a wall for folding blankets'. In Ishkashim and Wakhan dialects of Badakhshan region the unit [katak] gives the meaning of 'a hung cradle' (ROZENFEL'D, 1971, p. 115).

The unit [katak], i.e., a little kat 'made of wood', points to a single semantic meaning to the word [kat] 'throne', 'wooden cot', etc. (NEMENOVA; JURAEV, 1980, p. 114). But, however, in some dialects of Iran and northern dialects of Tajikistan this word is far from the meaning of the word [kat]. In some dialects of the Persian language [katak] gives the meaning of 'short-legged sheep' (RUBINCHIK, 1983, p. 309). This unit is in the northern dialect of the Tajik language is used in two homonymous meanings: [katak] I. 'coop', 'places for poultry'; [katak] II 'fabric in a cage.'

In accordance with the problem of our study when considering the theoretical and practical issues related to its specific aspects, the methods of linguistic description and comparative linguistics served as an important theoretical and methodological base for our scientific research. In addition to these methods in this work the methods and principles of research of the domestic and foreign scientists-linguists were considered.

The basis of theoretical and methodological research was the conceptual provisions of the scientific research in the field of the issues related to the language teaching in schools and universities. The comparative method and the diachronic typology method is of a great importance. It allows you to trace the interconnections between the linguistic phenomena and the interlingual homonyms to determine their classification by the type of linguistic changes. 


\section{Results and discussion}

\section{Linguistic and specific characteristics of interlingual homonyms}

The research of linguistic and specific characteristics of interlingual homonyms and consideration of situations in which corresponding class of homonyms is used, one of the possible approaches to the description of their specific features, in our view, is the claim that only those groups of homonyms can be qualified as cross-lingual that are corresponding in two languages, first of all, on the phonetic appearance, but having different meanings (semantics). The degree of remoteness of the homonymous words` meanings can be different.

The study of the interlingual homonyms in terms of their features, and reviewing the situations in which they are used in the Persian and Tajik languages, shows possible approaches to the description of their semantics.

In our opinion, the cause of semantic innovation in interlingual homonyms system can be in the contacts with the languages of a different structure (Persian, Tajik, Dari), although the contacts show the diversity of lingual situations whose evolutionary consequences can be very different. Maybe sometimes language contacts accelerate the evolutionary inertia (the motion state) interlingual homonyms, i.e., the trends, determined by their peculiar properties, as well as by the inner aspiration to the new forms of expression and changes. This may explain sometimes the parallelism of the evolution of typologically close, but areally separated by semantics the interlingual homonyms.

The object of a diachronic typology of the interlingual homonyms can be their classification by type of the linguistic changes. If this problem is confined to a historical group of homonyms, quite often there is an opportunity to present them as examples of the different classes of words, as the successive stages of the implementation of a long historical lingual trend or as a product of the different stages of a single process.

\section{The typology of interlingual homonyms}

Interlingual homonyms issue, no matter how the meanings of these words are interconnected, i.e., whether these meanings are homonyms or are still in the stage of polysemy, first of all, it is of a great practical importance for the teaching of Persian language. Therefore, we consider the problem as a whole, not limited to the separation of the 'polysemy' category and 'homonyms'. 
For example, the word [panjare] in the modern Persian language means 'window', and in the Tajik language is used in the sense of 'bars'. Here we see a great distance between the meanings.

The word [sandali] in Persian means 'chair', and in Tajik retained its original meaning 'a low table to warm the feet, which is placed over the recess with hot coals and is hid with a blanket'. The remoteness of the meanings of this word is not so large as in the first case (in both cases - the seating position).

Another word that is considered to be cross-lingual homonym in these languages [čakka] or [čekke] has the following meanings:

[čakka] or [čekke] I 'a drop', 'flow'; in this meaning it is used in Iran, Tajikistan, and Afghanistan

[čak(k) a] II 'temple', 'ustuhoni chak(k)a' 'temporal bone', known in the Tajik language.

[čakka] or [čekke] III 'thick', 'sour milk', and this meaning is used in Tajikistan and Afghanistan.

[čakka] IV colloquial. 'side', 'edge of smth.', is known in the Tajik language (YUZMUKHAMETOV; VDOVIN, 2016).

Also, this unit is used in the dialects of the residents of Herat and its environs (Afghanistan) within the meaning of 'clapping, applause' known and most used in the component with the verb [zadan] 'beat, hit', and sustained phrases like: [ba eftekhor-i arus-u doomad chakka bizan] 'meet newlyweds clapping hands, applauding', etc.

[čakke] or [čekke] $\mathrm{V}$ in the Iranian dialects, Ahvaz and Azerbaijan, the following meanings: 1. 'small'; 'not big'; 2. 'joker'.

The word [čooruk] is also a cross-lingual homonym and is used in the following meanings:

[čooruk] I in the modern Persian language has two homonymous meanings: 1.'wrinkle'; 'fold'; 'bending', in a complex with the verbs [chooruk khordan, chooruk bardoshtan, chooruk oftodan] gives the meaning of 'to pucker', 'to wrinkle'; 2. 'rotten', 'spoiled'. (YUZMUKHAMETOV; VDOVIN, 2016).

[čooruk] II in the dialects of the peoples of Afghanistan is used to mean 'narrow, tight clothing'. 
[čooruk] III in the northern Tajik dialects this word is used in the meaning of 'old', 'worn out'; 'old'. In the dialects of Istaravshan, the component phrases 'odami churuk, vay churuk shudagi, judoyam churuk...' gives the meaning of 'a thin, skinny man'.

The unit [sheleng] is known in the dialects of modern Persian and Tajik languages, which has antonymous meaning in these dialects:

[sheleng] in the dialects of Chahorlang Bakhtiyari it means 'to go', 'to go fast', 'a big step' (SARLAK, 1381).[sheleng] in the northern dialects of the Tajik language is used in the general meaning of 'foot' as part of the phrase 'shilingi poj', and is sometimes used to mean 'slow walk and walk on quietly' in the component of the double-word 'shiling-shilling.'

Along with nouns and adjectives, some verbs also have homonymous meanings, for example the verbs [darāmadan] and [darāvardan]. The verb [darāmadan] in all languages is 'enter'. In addition, in the Persian language gives another antonymous meaning 'get out, go outside' and therefore should be considered as homonyms. In this case, the second part of the word in Persian by the rule of spelling and word-formation of the Persian language, i.e., infinitive, thereafter, is written separately from the prefixe (درآمدن). It should be noted that in making verbal prefixes in both languages there are different wording or word-formation structure: [medarāyam] ('enter' in Tajik), [darmeāyam] ('enter' in Persian), as we see, sometimes prefixes change their position. In the meaning 'get out' this verb [darāmadan] is used in the famous Persian proverb [az āb darāmadan] 'turn out, come out'.

The unit [parparak/perperak/pirpirak] is one of those homonyms, which appeared on the basis of the semantic meaning of the infinitive [paridan] 'fly' and its verb stem [par] has the following meanings:

[parparak/pirpirak] I in the northern dialects of the Tajik language is used in the meaning of 'kite', or 'toy-spinner made by hand', and 'a taped piece of paper attached to the wooden handle, which rotates in the wind, like a helicopter propeller'.

[perperook/perperak] II in the dialects of the language of Bakhtiari is known with the meaning of 'butterfly' (SARLAK, 1381, p. 62). These words refer to two different things, at first glance, it seems to be completely different, but in the semantic field of the words are the same, the same feature 'to fly' or 'to spin' preserved its semantic meanings. And also the cognates, some nouns are formed through differences of initial meanings.

The unit [dāman] is one of such interlingual homonyms, which has the following meanings: 
[dāman] I a 'skirt' in the modern Persian language.

[dāman] II in the northern dialects of the Tajik language means 'a small cloth for shaking fruits from fruit trees, and for carrying cargo items'. The component of a compound word [peshdāman] also used for this meaning. Usually, [peshdāman] is in the meaning of 'an apron for putting the harvest'. Also, the unit [dāman] in the component phrase [dāmane korta] gives the meaning of the 'hem of dress.'

\section{Summary}

Thus, the theoretical importance of the problem of distinguishing of intra and external factors of evolution of the interlingual homonyms in the Persian and Tajik languages, as well as the differences of these two factors on the functional-semantic zone of their semantic transformation is clear.

The interlingual homonyms is a characteristics of the dialects, and therefore we call them dialectal homonyms. These units appeared in the process of the historical transformation of the language or were borrowed from other languages. This includes the homonymous such units as [čakka, čooruk, kat, pirpirak, sheleng], etc.

Regarding the changes and differences in the lexica of the Tajik, modern Persian and Dari-Afghan languages, the linguists-Orientalists have carried out many scientific studies. Among them the works of Iranian scientists, Bahar (2008) 'Development of the Persian language for 29 centuries' and 'The Language of Dari' (Zabane dari), a scientific article by Dr. Hanlyari (2008) 'Change and Development of Persian-Dari (Pehlevi- Farsi, Dari), by Murtazo Razmoro (1384) 'Persian and Tajik: two different types of Farsi', 'Tajikian Farsi: which way to develop', as well as the scientific works by outstanding orientalists Bertel's (2008) 'PersianDari-Tajik', Lazar (2008) 'The common language of Iranian lands and its dialects in the texts of 9-11th centuries', by Professor Amonova (1370) 'On the differences of Iranian Farsi and Tajik (Farsi)' and many others, where we find interesting reflections on the linguistic issues.

Even in the 1930-40s the Tajik educator Ayni in the newspaper 'Tajik Voice', 'Overview of Knowledge', 'Bukhoroi sharif' raised the issues of lexical changes of these languages, which occurred under the influence of foreign borrowing (GOLMORADZADA, 2007, p. 231).

This problem has not gone unnoticed in Iran, which caused restlessness and discontent among such scholars as Dehhudo and Moin (2008). This phenomenon was widely discussed in the articles by Bahar (2008), Hanlyari (2008): 'Dari Farsi, which from the early 4th century to 
the early 7 th century, gradually became the official and literary language of Iran, and undergone changes not only due to eastern Iranian dialects, but also due to foreign languages. These changes have been associated with the adoption of the borrowings, and sometimes the formation of new words and expressions' (HANLYARI, 2008, p. 235). Bahar formulated his opinion on the changes of the modern Persian language as follows: '...Yes, in fact, today Iranian language cannot be called the language of Dari, as it is in its sixth stage of the development, it should be called 'the language of the pen' (lafze qalam)' (BAHAR, 2008; RUBINCHIK, 1983).

The dialectologist Ali Ravaqi said about the changes of the modern Persian language and its development as follows: 'For a complete study of the development of the current Persian language, you should know that the Persian language in all written texts is not the same Farsi language. This language in certain geographic parts and parts of its distribution mixed with the local dialects and formed another new kind of Persian language, which is distinguished by its phonetic and lexical features' (AMONOVA, 1370, p. 26).

\section{Conclusion}

It should be emphasized that this opinion is not intended to wholehearted separation of the Persian, Tajik and Dari languages, but it is the analysis and characterization of today's reality, the relationship between these related languages.

According to F.Amonova 'The Persian spoken language has its own characteristics, and the ignorance of these specifics will cause misunderstanding when communicating with the Iranians, as well as when reading the modern literary works' (AMONOVA, 1370, p. 26).

Indeed nowadays there is such a tendency, the special direction of the modern Iranian literature, when the prose writers more and more use local dialect words in their works, namely in the speech of the characters, and in the speech of the authors. And this, of course, lead to misunderstanding or mistranslation of the texts. During the lessons we have seen that the students understand the basic idea through the literary words and do not understand the dialect of a particular region, or when retelling the text they make mistakes and mistranslate (SUBICH; MINGAZOVA; SHAMSUTDINOVA, 2018, p. 150).

Given these characteristics, the lexical differences of the vocabulary of these languages should be remembered, and therefore in this regard the interlingual homonyms in the dialects of Iran, Tajikistan and Afghanistan should be regarded as a positive or useful phenomenon. 


\section{Recommendations}

The material of the article is of interest to specialists who are engaged in teaching of the modern Persian, Tajik, Dari languages, reading and preparing lectures on the lexicology and dialectology of Persian, Tajik, Dari in the universities.

ACKNOWLEDGEMENTS: The work is performed according to the Russian Government Program of Competitive Growth of Kazan Federal University.

\section{REFERENCES}

AMONOVA, F. R. O razlichij farsi Irana i tadzhikskogo (farsi). Sbornik stat'ej po yazykoznaniyu. Tegeran, 1370. p. 26-31.

BAHAR, M. Razvitie persidskogo yazyka v techenie 29 vekov. Vosemnadcat' stat'ej. Hudzhand: Nuri ma'rifat, 2008. p. 13-22.

BERTEL'S, E.EH. Persidskij-dari-tadzhikskij. Vosemnadcat' stat'ej. Hudzhand: Nuri ma'rifat, 2008. p. 249-264.

DAVLATOVA, M. Glagol'naya leksika i glagol'noe slovoobrazovanie v 'Zajn-al-ahbor'. Dushanbe, 1969. v. 11.

GOLMORADZADA, P. Yazyk i nacional'noe samopoznanie. (Sbornik stat'ej). Kniga pervaya. Dushanbe: Pajvand, 2007. 231 p.

HANLYARI, P. N. Izmenenie i razvitie persidskij-dari (Pekhlevi-farsi-dari). Vosemnadcat' stat'ej. Hudzhand: Nuri ma'rifat, 2008. p. 222-248.

LAZAR, Z. H. Obshchij yazyk iranskih zemel' i ego dialekty po tekstam 10-11 vv. n.eh. Vosemnadcat' stat'ej. Hudzhand: Nuri ma'rifat, 2008. p. 99-109.

MOIN, M. Farhange farsi-ye Moin (yek jeldi). Chape yazdahom. Tehran. (Muin M. Slovar' persidskogo yazyka Muina (odnotomnyj)). Izdanie odinnadcatoe. Tegeran, 2008.

NEMENOVA, R. L.; JURAEV, G. Yuzhnyj dialekt tadzhikskogo yazyka. Fonetika, leksika. Dushanbe: Donish, 1980. t. 1, 331 p.

ORANSKIY, I. M. Vvedenie v iranskuyu filologiyu. (Perevod na persidskij Karim Keshavarz). Tegeran: Entesharate Pejam, 1359. 358 p.

OTHEGUY, R.; GARCÍA, O.; REID, W. Clarifying translanguaging and deconstructing named languages: A perspective from linguistics. Applied Linguistics Review, v. 6, n. 3, p. $281,2015$. 
RAZMORO, M. Persidskij i tadzhikskij: dva raznyh vida iz yazyka farsi. Sbornik stat'ej Universiteta Ferdousi. Tegeran: Nameje parsi, 1384. p. 23-28

ROZENFEL'D, A. Z. Badahshanskie govory tadzhikskogo yazyka. Leningrad: Leningradskij gosuniversitet, 1971. $119 \mathrm{p}$.

RUBINCHIK, U. A. Persidsko-russkij slovar'. Moskva: Russkij yazyk, 1983.

SARLAK, R. Slovar' dialektov yazyka bahtiyari Chaharlanga. Tegeran: Osor, 1381.

SHUKUROV, M.; KAPRANOV, V. A. Tolkovyj slovar' tadzhikskogo yazyka. Moskva: Sovetskaya ehnciklopediya, 1969.

SUBICH, V. G.; MINGAZOVA, N. G.; SHAMSUTDINOVA, E. K. Comparative analysis of English, Arabic and Tatar national corpora. Journal of Language and Literature, v. 7, n. 2, p. 150-154, 2016.

\section{How to reference this article}

AKHMEDOVA, M. N.; YUZMUKHAMETOV, R. T.; ABROROV, I. M.; BELOGLAZOVA, I. G.; Azim BAYZOEV, A. Lexical features of interlingual homonyms in modern persian, dari and tajik. Rev. EntreLínguas, Araraquara, v. 7, n. esp. 3, e021051, Sep. 2021. e-ISSN: 24473529. DOI: https://doi.org/10.29051/el.v7iesp.3.15711

Submitted: 10/01/2021

Required revisions: 20/03/2021

Approved: $23 / 06 / 2021$

Published: 01/08/2021 